CHAPTER THIRTY-TWO

\title{
BASIS OF CRIMINAL ACCOUNTABILITY
}

\section{The System of International Criminal LaW}

The principle of international criminal responsibility constitutes one of the most important principles for the implementation and enforcement of the provisions of international criminal law on the perpetrators of international crimes. This principle has been developed and enlarged from a number of international criminal conventions governing the law of armed conflicts and was particularly consolidated by the establishment of the International Military Tribunals after the Second World War and the creation of the United Nations Organization. The Tribunals were mostly effective in the development of the concept of the international criminal responsibility of individuals and the prosecution and punishment of perpetrators of war crimes in connection with the Second World War. The legal effect of the law of the Tribunals can particularly be examined in the provisions of a number of international criminal documents applicable to international crimes. ${ }^{1}$

The principle of the international criminal responsibility of individuals is rather controversial when there is a question of superior order or the plea of superior order for individuals who wish to evade prosecution and punishment. This is one of the reasons that the perpetrators of international crimes have normally been successful in avoiding the application of criminal sanctions. However, the International Criminal

1 To note only a few: the Geneva Convention for the Amelioration of the Condition of the Wounded and Sick in Armed Forces in the Field, 12 August 1949, the Geneva Convention Relative to the Treatment of Prisoners of War, 12 August 1949, the Geneva Convention Relative to the Protection of Civilian Persons in Time of War, 12 August 1949, Protocol I Additional to the Geneva Conventions of 12 August 1949, 12 December 1977, Protocol II Additional to the Geneva Conventions of 12 August 1949, 12 December 1977, the Convention on the Prevention and Punishment of the Crime of Genocide, 9 December 1948, the International Convention on the Elimination of All Forms of Racial Discrimination, 7 March 1966, the International Convention on the Suppression and Punishment of the Crime of Apartheid, 30 November 1973 and the United Nations Convention on the Rights of Child, 20 November 1989.

This is an open access chapter distributed under the terms of the CC-BY-NC License. 
Tribunals after the Second World War strongly rejected the plea of superior order as a reason to escape prosecution and punishment. Consequently, a perpetrator of international crime cannot free himself from the application of criminal sanctions by reasoning that he has acted due to a superior order or government command. It is for this reason that individuals bear criminal responsibility for violations of the principles of international criminal law. This has been proven in the practice of international criminal tribunals and courts.

The principle of the international criminal responsibility of individuals is originally based on the assumption that individuals are the most essential characters in the commission of international crimes and therefore liable to prosecution and punishment and this is regardless of their official position and includes heads of states or governments. Thus, in the system of international criminal law by the term 'international criminal responsibility of individuals' we mean all those who have, in one way or another, participated in the commission of certain acts constituting international crimes.

The principle of criminal responsibility also extends, in certain circumstances, to the concept of criminal responsibility of organizations and states. It is on the ground of this legal extension that the 1973 Convention on Apartheid recognizes the concept of criminal responsibility of Organizations involved in criminal activities constituting apartheid. Article 19 of the work of the International Law Commission on State Responsibility has also stated the important function of the concept of the international criminal responsibility of states, the legal interpretation of which includes also individuals' criminal responsibility under the system of international criminal law. ${ }^{2}$

It is however important to emphasize that the principle of the international criminal responsibility of individuals, organizations and states, because of a lack of juridical and political agreements, has not been

2 The principle of criminal responsibility in international criminal law is more controversial when attributed to states in cases of the commission of international crimes. The notion of international criminal responsibility of states has, essentially, been developed since the early 1920's alongside the concept of criminal responsibility of individuals in international criminal law. The notion has, particularly, been extended by the work of the International Law Commission on the general subject of the international responsibility of states and Article 19 on 'the International crimes and international delicts' of the Draft Articles on International Responsibility of States relates to this matter. There is, however, not yet any particular consolidation of the concept of international criminal responsibility of states in international criminal law. The position has not therefore been juridically or politically settled. 
strongly employed in the system of international criminal law. Individuals' criminal responsibility has recently been enforced by the ICTY, the ICTR and the Sierra Leone Court. The courts have ad hoc characters and have been created by the United Nations. The ICC is also trying to a limited extent to apply the concept of the international criminal responsibility of individuals. The Court is only successful upon the weak and it seems that the jurisdiction of the Court has no legal authority over the strong. Thus, the impunity is encouraged by the indirect policy of the Court. Other factors such as the reluctance of states to yield their legal power to the jurisdiction of the Court and the disinclination of political powers in each state of the world to accept the concept of criminality of their leaders have also been effective in the non-implementation and non-enforcement of the provisions of the system of international criminal law. ${ }^{3}$ These are some of the basic reasons why a great number of international criminals have escaped from prosecution and punishment. ${ }^{4}$

${ }^{3}$ A report from the World Conference on the Establishment of an International Criminal Tribunal to Enforce International Criminal Law and Human Rights points out the following factors for the lack of establishment of an international criminal court. These are: "(a) Continuing conflict between national interests; (b) The reluctance of states to yield any part of their sovereignty; (c) Chauvinism in regarding one's own national laws as superior; (d) The dangers inherent in the establishment of yet another international bureaucracy with possibly minimum benefits to the world community; (e) The difficulty in agreeing on the subject-matter jurisdiction of an international tribunal; (f) Concerns about the selection of an international judiciary; $(\mathrm{g})$ The conflict of an international system of criminal justice with national jurisdictions; (h) The remoteness of an international criminal justice system from the peoples of the world; (i) The difficulty of agreeing on a general part; ( $j$ ) The difficulty of agreeing on procedural rules; (k) The role which individual states should play in the international criminal justice process; (l) The problem of invoking (initiating) the international criminal justice process; (m) The cost to the international community; (n) The lack of enforcement power of an international criminal tribunal, and above all, (o) The concern that the International Criminal Court might dispense 'victor's justice.'” World Conference on the Establishment of an International Criminal Tribunal to Enforce International Criminal Law and Human Rights, in Cooperation with the United Nations, A Satellite Conference to the 1993 World Human Rights Conference, Siracusa, December 2-5, 1992, 49 pp., p. 6.

${ }^{4}$ The commission of serious international crimes, especially the international crimes of genocide, crimes against humanity, war crimes and torture in the former Yugoslavia against the Muslim nationals by Serbians are the most effective reasons for the establishment of a temporary international criminal tribunal (ICTY) for the prosecution and punishment of the perpetrators of international crimes. 


\section{ISLAmic INTERNATIONAL CRIMINAL LAW}

\subsection{The General Concept}

The concept of responsibility in Islamic law is, by itself, a separate institution. This is because the provisions of Islamic law cannot properly be enforced without the concept of the responsibility of its subjects. Thus, responsibility in Islamic law constitutes the core principle of the implementation and application of the principles of Islamic jurisdiction. Islamic law recognizes various types of responsibility for its subjects including moral, civil, contractual, brotherhood, family, neighbourhood, social, economic, taxation, universal and, criminal responsibility. The concept for all these types of responsibilities is essentially based on breaches of the Islamic code of behaviour.

Islamic law attributes the concept of criminal responsibility exclusively to individuals and therefore bases the concept of responsibility of the offenders on intentional or deliberate abuse of the freedom of choice in their social or international conduct. ${ }^{5}$ It is on this theory that Islamic law does not agree with any other opinions regarding the concept of the criminal responsibility of individuals. For example, one of the chief differences between the Islamic concept of criminal responsibility and other criminal systems has been that Islamic jurisprudence totally contradicts the opinions of those earlier European writers who advocated that certain persons may habitually commit crimes and are therefore 'born criminals.' One clear example is Cesare Lombroso, the Italian criminologist who was the founder of the Italian School of positivist criminologist. According to him, the concept of criminality was inherited by persons. ${ }^{6}$ Such an assumption is totally rejected by the Islamic jurisprudence of criminal law and according to it all crimes are, almost, essentially avoidable and not inevitable whether committed socially, generally or in the international conduct of individuals. In other words, the soul/spirit of all

\footnotetext{
${ }^{5}$ Moreover, 'The concept of personal responsibility is associated with the principle of equality and uniformity in punishment. It is a fundamental Islamic belief that every adult offender is responsible and should be punished for his crime. Moreover, penalties are to be inflicted equally on all, regardless of distinctive characteristics such as race, religion, colour sex, language, ethnic background or social class.' Lippman, Matthew, Sean McConville, and Mordechai Yerushalmi., Islamic Criminal Law and Procedure, p. 81.

${ }^{6}$ One of his writings was mainly published in many languages in Europe. Cesare Lombroso, L'uomo delinquente (1878).
} 
individuals is free of $\sin$ and $\sin$ is the result of the actual conduct of a person in his/her temporary life and is not therefore substantive in the spirit of man.

It must, however, be added that Islamic law places great emphasis on the philosophical and spiritual idea that God is aware of the nature of man including his will, thoughts and desires and therefore God knows the fate of man. In spite of all this, it is still the person alone who decides his/her destiny, actions, will, good and evil deeds. The reason for this is that an individual generally has the capacity for thinking, choosing and understanding. God has given man the ability to be good and do good and whatever action a person may therefore take, it is his/her own desire and choice, although God is already omniscient of all actions during a lifespan; God is omnipotent.

The concept of criminal responsibility in Islamic law may be mitigated or even deleted under certain circumstances. This is when an action by a person is carried out without deliberation or unintentionally and the principle of the freedom of choice is lacking in those actions. This includes such conditions as duress, immaturity and mental disability including insanity. In these cases the concept of criminal responsibility cannot be attributed to an accused person who has unintentionally violated the law. However, in the cases of disability a guardian may be accountable before the Islamic criminal jurisdiction.

\subsection{International Aspects}

The concept of criminal responsibility of individuals in Islamic international criminal law is, more or less, similar to the concept of criminal responsibility in positive international criminal law. This is because Islamic international criminal law bases the concept of criminal responsibility of persons on the element of intention and consequently intention constitutes one of the essential elements for the imputation of the concept of criminal responsibility to the perpetrators of international crimes. Unintentional acts are not therefore classified under the concept of responsibility. For example, in time of war 'Muslim soldiers have to take care that they do not fire directly on neutrals, women and minors and other non-combatants, yet if any damage is done to them unintentionally, no responsibility is to be placed on the Muslim army.7 This

\footnotetext{
${ }^{7}$ Hamidullah, The Muslim Conduct of State, p. 194.
} 
concept should not however release an Islamic state from the consequence of damages for the purpose of reparation.

In Islamic international criminal law only the perpetrators of international crimes bear the concept of international criminal responsibility and this responsibility is applicable to all persons who participate in the commission of international crimes. The concept applies regardless of their legal and political positions within the state system. Some of these international crimes involving the concept of the international criminal responsibility of individuals for violations of Islamic provisions of international criminal law include war crimes, crimes against humanity, mass killing or systematic destruction (genocide), aggression, drug offences and involvement in activities concerning obscene materials. ${ }^{8}$

One important point in the application of international criminal responsibility under Islamic international criminal law is that the violated legal provisions must be de lege lata and in all aspects of criminal jurisdiction the principle of legality must always be respected by all judges. ${ }^{9}$ This is an important point in the protection of the criminally accused before the process of any criminal jurisdiction.

It must be emphasised that since all international crimes in Islamic international criminal law are treated under the principle of universality, because of their effects on mankind, all Muslim states are (according to the Islamic principles) authorized to prosecute and punish the perpetrators of international crimes which have come under their jurisdiction. On the grounds of political considerations, this theory may however not be respected by Islamic nations in practice. The consolidation of the theory is nevertheless a fact under Islamic jurisprudence of law. The theory is originally based on the assumption that all Muslim states are equal before divine law and that a serious violation of Islamic international criminal law can be regarded as a serious violation against all Muslims. In contrast to this, in the system of international criminal law, all international crimes cannot, at the present time, be treated under the principle of universality and there are only a few international crimes which are considered crimes against mankind and treated with the universality principle. These are such crimes as piracy, war crimes, genocide, crimes against humanity and narcotic offences. The theory of universality is, however, continuously extending in the international arena.

${ }^{8}$ For an examination of these international crimes under the system of Islamic international criminal law see the relevant chapters.

${ }^{9}$ See part one, chapter one. 


\subsection{High Ranking Officials}

Islamic international criminal law has, basically, promoted the concept of fear and appropriate justice in relations between superior or higher officials and others who come under their supervision. For example, the earlier practice of Islamic international criminal law provided full instruction concerning the decisions of commanders in the course of war. It requested that they should, in all situations, fulfil the humanitarian provisions of Islamic international criminal law and fear God regarding the treatment of those who accompany them. Some of these instructions can be found in the second source of Islamic law i.e. the Sunnah or exclusively in the traditions of the Prophet of Islam. Their provisions may adapt themselves to the circumstances of the present time governing the activities of superiors and the treatment of those who are at war with Muslims. According to one instruction by the Prophet, 'Fight ye all in the path of God and combat those who do not believe in God. Yet never commit breach of trust nor treachery nor mutilate anybody nor kill any minor or woman. This is the pact of God and the conduct of His Messenger for your guidance. ${ }^{10}$ This type of significant instruction by Muhammad the Prophet of Islam to commanders, superiors or high ranking officials of armed forces or government departments continued during his lifespan and can now be regarded as one of the chief reasons for the promotion of Islamic humanitarian regulations during armed conflicts.

The successors of the Prophet commanded the high ranking officials or superiors of armed forces to:

'remember ... 'Souvenez-vous, disait-il à ses généraux, que vous êtes toujours sous les regards de Dieu et à la veille de la mort; que vous rendrez compte au dernier jour ... Lorsque vous combattrez pour la gloire de Dieu, conduisez-vous comme des hommes, sans tourner le dos, mais que le sang des femmes, ou de celui des enfants et des vieillards, ne souille pas votre victoire. Ne détruisez pas les palmiers, ne brûlez pas les habitations, les champs de blé, n'abattez jamais les arbres fruitiers, et ne tuez le bétail que lorsque vous serez contraints de le manger. Quand vous accordez un traité ou une capitulation, ayez soin d'en remplir les clauses. A mesure que vous avancerez, vous rencontrerez des personnes religieuses qui vivent dans des monastères (moines) et qui servent Dieu dans la retraite: laissez-les seuls, ne les tuez point, et ne détruisez pas leurs monastères ... ${ }^{11}$

${ }^{10}$ Hamidullah, The Muslim Conduct of State, p. 299.

11 'Siyer. t. I, pp. 30-38;-Ockley, La Conquête de la Syrie, de la Perse et de l'Egypte par les Sarrasins, t.I, pp. 22-27, etc.; Gibbon, The Decline and Fall of the Roman Empire (1837), vol. II, p. 449.' Quoted in Rechid, 'L'Islam et le Droit des Gens', pp. 451-452. 
The model of instructions for commanders must be read in conjunction with chapter on war crimes which lists the prohibited acts during an armed conflict and recognizes their violations as constituting war crimes and giving rise to the concept of international criminal responsibility of the perpetrators. This means that the activities of high ranking officials are limited during a war and must conform to the humanitarian principles of Islamic international criminal law. It also means that a person acting as pursuant to an order of a superior may not be permitted to be relieved of criminal responsibility for the violation of the law of armed conflicts.

In a comparative analogy, the provisions of Islamic international criminal law concerning the limitation of the scope of activities of superiors and the system of international criminal law are parallel and the scope of their applicability may, in many aspects, overlap each others' provisions. This is because both systems of international criminal law and their criminal justice put considerable weight on the recognition of the criminal responsibility of superiors, commanders and even the head of states. The Statue of the ICC has particularly provided several articles under the provisions of which the criminal responsibility of certain persons is strongly consolidated. In fact, the Court is permitted to put an end to the impunity of heads of states, commanders in chief and superiors. Generally speaking, international criminal justice and Islamic justice prohibit the shielding of perpetrators from criminal responsibility for crimes against humanity, war crimes and genocide. Some of the most significant provisions of both systems are the followings:

- Individuals have criminal responsibility for the violation of their provisions.

- Different forms of immunities which may be attached to the official capacity of a person whether empowered by national and international organizations, states and different forms of governments do not prevent the attribution of the concept of international criminal responsibility to that persons.

- The concept of individual criminal responsibility applies to all persons without any distinction stemming from their official capacity.

- The official capacity of persons as a head of government, a member of a government or other similar capacities do not exempt that person from international criminal responsibility. 
- To take all reasonable measures for the prevention of criminally wrongful conducts is the duties of a superior. He/she may therefore bear criminal responsibility for the failure to comply with his/her duties.

- All persons acting or having the function of military commanders have the international criminal responsibility for the commission of certain crimes under both legal systems.

- The superiors have the international criminal responsibility for the acts of their subordinates because of their duties and liabilities to have effective control over their conducts.

- A failure to prevent subordinates from committing crimes calls upon the criminal responsibility of superiors.

- A superior, commander, head of state or government may be held criminally responsible for the grave violations of international humanitarian law of armed conflicts.

\section{Islamic Components of Responsibility Within the ICC}

As we have demonstrated elsewhere, both concepts of law i.e., Islamic criminal jurisprudence and the system of international criminal jurisdiction recognizes the concept of the international criminal responsibility of individuals for the violations of their rules. Islamic law deals in fact with all the concepts of crimes found within the framework of the ICC. Thus, in Islamic criminal jurisdiction similar to the Statute of the ICC, responsibility is based on three key elements. These are legal, physical, and mental elements.

The legal element of criminal responsibility refers to the infringement of a legal norm of criminal law. This implies also an actual or potential injury to one of the subjects of law. The legal element also creates the concept of the attribution of criminal responsibility to a person. Thus, pure Islamic jurisdiction applies the concept of criminal responsibility to all actors without due regard to their ranks. The attribution of the concept of criminal responsibility may, therefore, similar to the criminal jurisdictions of the statutes (the ICTY, the ICTR, and the ICC) include the accountability of the individual, her/his mens rea and his/her responsibility for the consequence of crimes.

The physical element refers to the direct engagement of the person in a criminal conduct. The physical element does not only mean a direct physical involvement in the commission of the relevant crime, 
but, it means also other types of engagements such as direct and indirect assistance, giving and providing instructions.

The mental element of the crime refers to the material elements which are actually the basis of criminal responsibility and liability for punishment. This means that the international crime is committed with the intent of the perpetrator and with his/her knowledge. These three principles are, generally, the basis of criminal responsibility in Islamic criminal jurisdiction and are also regarded as an integral part of the Statute of the ICC. ${ }^{12}$

\subsection{Age of Criminal Responsibility}

The attribution of the concept of criminal responsibility is indeed very complicated. The question is more problematic when the age of the accused person is involved and whether he/she bears criminal responsibility for the criminally wrongful conduct. Within the early Islamic criminal justice, the practice sometimes depended on the gravity and the cultural attitudes of the perpetrator and whether he/she had completed certain physical requirements. The practice has, however, been changed and due to the appropriate interpretation of Islamic rules as well as the entrance of the Islamic nations into international conventions on human rights law, the age of criminality has to be in conformity with international standard. Different theories for the defence of criminal responsibility of young age are weak and non-acceptable. A person may not be recognised criminally responsible when she/he has not attained the age of $18 .{ }^{13}$ This age has also been strongly supported by the Islamic instruments of human rights law. The requirement of 18 years old is also supported by the ICC Statute. It reads clearly that "the Court shall have no jurisdiction over any person who was under the age of 18 at the time of the alleged commission of a crime." While, the words of the ICC are clear, the Statute is silent concerning the position of persons who are under eighteen years old.

\subsection{Intention}

We have noticed that Islamic international criminal law puts a heavy weight on the principle of intention or fault. But what the criteria are for this intention is rather complicated. The Islamic jurisdiction encour-

\footnotetext{
12 Article 30.

${ }^{13}$ However see other opinions. Don Cripiani, Children's Rights and the Minimum Age of Criminal Responsibility: A Global Perspective (2009), pp. 79-82.
} 
ages justice through good thoughts and good actions. However, this does not necessarily mean that bad thoughts are also officially prosecutable. In other words, good thoughts and actions refer inter alia to respect, nonviolations, non-breach of moral, oral or legal contracts including physical and psychological. It is based on the spiritual and natural strength of a person not to violate the Divine law. Bad thoughts, as long they as are not, in one way or another, performed do not necessarily require punishment under Islamic law, but, decrease the morals and trust of a person in the spiritual rights of human beings. Thus, bad intention is not punishable, as long as, it is not jointed or shared with others. Nevertheless, this intention may, strongly, encourage other persons to carry out certain actions/functions which are not necessarily physical, but, solely psychological. Therefore, mens rea under the jurisdiction of Islamic international criminal law constitutes rather the specific psychological encouragement of a person in a given event. This psychological characteristic emerges from the knowledge and desires of the person. It means the person has the actual knowledge of the fact and possesses the necessary knowledge due to the provisions of criminal regulations.

Thus, in Islamic criminal jurisdiction fault "must be proven during the procedure of jurisdiction; as long as existing evidence does not prove that the defendant's conduct was criminal, his responsibility will be subject to debate. Thus, specific intent must be shown that leads to a definite result, or dolus evenualis (eventual intent), that also has the same result. Both positions denote deliberate intent."14 Consequently, a casual relationship between the act committed and the resulting act has to exist. ${ }^{15}$ Similarly, the system of international criminal prosecution puts considerable weight on the intention of the perpetrators. This intention can be physical or psychological. For instance, the ICTY concerning the intention of the perpetrators against Muslim population of the Herzegovina stated that many of those acts "constitute inhumane acts and are crimes against humanity committed during an armed conflict as part of a widespread or systematic attack on a civilian population and that the accused intended for discriminatory reasons to inflict severe damage to the victims' physical integrity and human dignity. The Trial Chamber further finds that the accused in some instances was himself the perpetrator and in others

\footnotetext{
${ }^{14}$ Malekian, 'The Homogeneity of International Criminal Court with Islamic Jurisprudence', p. 611.

${ }^{15}$ Ahmad Fathi Bahnassi, 'Criminal Responsibility in Islamic Law', in M. Cherif Bassiouni (ed.), The Islamic Criminal Justice System, p. 172.
} 
intentionally assisted directly and substantially in the common purpose of inflicting physical suffering upon them and thereby aided and abetted in the commission of the crimes." ${ }^{16}$ Due to the above statement, within international criminal jurisdiction intent can be of two forms. One is psychological and the other physical intention both of which demand the criminal responsibility of the perpetrator. This means that without prejudice to the sources from which the Islamic criminal jurisdiction or the international criminal jurisdiction arise both systems rely heavily on the intention of the perpetrators and its effect on the commission of criminally wrongful conduct. Yet, if a person attempts to commit a crime but regrets doing so, his/her responsibility may be reduced. This however depends on the situation.

\subsection{Participations}

Islamic criminal justice like the international criminal justice system pays especial attention to several acts which may result in the prosecution and punishment of the perpetrators. The word participation is therefore used in the title of this section to identify certain acts which may, in one way or another, be helpful in the commission of a crime. In the frame of the word participation one may find the words assistance, aid, complicity, abet, help, attempt, encourage, joint, cooperation, united, solicit and, contribution. These are when:

- he/she assists in the preparation and performance of criminal conduct.

- he aids and abets in the performance of the crime.

- Without involvement in the commission of a crime, he/she carries out his intention through another person.

- he/she orders, in one way or another, a violation of the system of international criminal law.

- he/she attempts to commit a crime.

- he/she knows or has sufficient knowledge that the crime is going to be committed.

- he/she encourages or incites others to commit grave violations.

- he/she jointly commits a crime with another person.

- he/she solicits the commission of the crime

- he/she contributes in the preparation or commission of the crime.

- he/she cooperates in the commission of a crime.

16 Tadic (IT-94-1-T), Judgement, 7 May 1997, para. 730. 


\subsection{Mitigations}

Like many other criminal legal systems, Islamic criminal law encourages the elimination and prevention of criminal conducts. For this reason, it seems that there are different ways to mitigate or reduce the responsibility of a violator of Islamic international criminal law. However, all reasons for mitigation must strongly be proven and there should not be any state of doubt. Similar provisions have been found under the system of international criminal justice. These are when:

- the accused is juvenile.

- the accused succeeds in preventing the completion of the crime.

- he/she voluntarily give up the criminal purpose.

- he/she has committed the criminal conduct exclusively on the basis of self-defence.

- he/she was under immediate pressure to protect others from a grave criminal conduct.

- He/she attempted or committed the crime because of threats or coercion by other persons.

- Sometimes intoxication may be seen as the reason for the mitigation of criminal responsibility. This is just in the case when the intoxication is non-voluntarily and is not based on personal intentions.

- The accused suffers from total insanity or mental disorder.

- The involuntarily use of strong narcotic substances by the accused.

- The accused is in a state of unconsciousness. This means he/she is totally unaware of the surroundings.

- A mistake of law may be a basis for excluding criminal responsibility.

\subsection{Joint Criminal Enterprise}

Islamic international criminal law condemns any criminal intrigue against mankind. According to the main source of the law "whoever killed a human being should be looked upon as though he had killed all mankind." ${ }^{77}$ Thus, it encourages peaceful relations between man and man and their cooperation to carry out an evil conduct is prohibited and is recognised as unjust. In this respect, it is stated that "guard yourselves against an affliction which may smite not only those who committed injustice among you in particular (but all of you)." ${ }^{18}$ In general, Islamic

\footnotetext{
17 The Qur'ān, 5:32.

18 The Qur'ān, 8:25.
} 
criminal justice applies punishment to all those who have, in complicity with one another, committed crimes against humanity, war crimes or genocide. $^{19}$

Under the recent development of case laws within the practice of the ICTR and in particular the ICTY, the concept of joint criminal enterprise has come into recognition. The concept aims to criminalize all acts of participation in different manners and forms for the accomplishment of a criminally wrongful conduct. This means the contribution of two or more persons in carrying out a crime. The theory was originally developed from the consequence of the Second World War and the murdering of innocent Jews under group criminal actions. A joint criminal enterprise requires, therefore, a common design, plan or purpose to commit a crime. This means that all defendants are answerable for the charges before a court.

Similarly, the Islamic criminal justice calls upon the criminal accountability of all those who have participated in the commission of a common plan to kill, murder, torture, forcibly evict civilians belonging to a particular ethnic group by destroying their civil services such as religious houses. According to the ICTY "a common, shared intention on the part of a group to forcibly remove members of one ethnicity from their town, village or region (to effect "ethnic cleansing") with the consequence that, in the course of doing so, one or more of the victims is shot and killed." ${ }^{20}$ Similarly, due to the provisions of Islamic justice and the Statute of the ICC, the killing of individuals on the basis of race, colour, culture, religion, language, ethnic origin, social and any other background are considered serious violations and the perpetrators of which have to be prosecuted and punished.

${ }^{19}$ Id.

20 The Tadic case (IT-94-1-A), Judgement, 15 July 1999, para. 204. 